\title{
Molecular markers and allelic relationships of anthracnose resistance gene cluster B4 in common bean
}

\author{
Belén Méndez-Vigo ${ }^{1}$, Cristina Rodríguez-Suárez ${ }^{1}$, Astrid Pañeda ${ }^{1}$, Juan José Ferreira ${ }^{2}$ \\ \& Ramón Giraldez ${ }^{1, *}$ \\ ${ }^{1}$ Departamento de Biología Funcional, Universidad de Oviedo, 33006 Oviedo, Spain; ${ }^{2}$ Area de Cultivos \\ Hortofrutícolas y Forestales, SERIDA, Apdo. 13, 33300 Villaviciosa (Asturias), Spain; \\ (*author for correspondence: e-mail: giraldez@uniovi.es)
}

Received 29 March 2004; accepted 2 December 2004

Key words: anthracnose, Colletotrichum lindemuthianum, common bean, Phaseolus vulgaris, SCAR marker

\begin{abstract}
Summary
Allelism tests and molecular marker analyses were combined to characterize the genes that, proceeding from the germplasm lines 'A493' and 'A321', confer resistance to bean anthracnose in the new breeding lines 'A1220' and 'A1231', respectively, developed through backcross breeding, using the dry bean landrace 'Andecha' as the recurrent parent. Allelism tests indicate that resistance to race 38 of anthracnose in genotypes 'A1220', 'A1231', and 'BAT 93' and in the differential cultivars 'PI 207262' and 'Mexico 222' is determined by different dominant alleles at the same locus. Therefore, the results obtained suggest that the so far considered as different genes $\mathrm{Co}-3$ (described as present in 'Mexico 222') and Co-9 (described as present in 'BAT 93') are alleles of the same gene. RAPD markers OB12 350 , OAH1 $18_{1100}$, and OY17 1100 and SCAR markers SI19 and SW12 were found to be linked to the resistance gene. Data indicate that the resistance genes to race 38 present in these materials are alleles of the same $\mathrm{R}$ gene cluster located in linkage group B4, because markers OY $17_{1100}$, SI19 and SW12 were previously linked to this cluster. The SCAR markers SB12 and SAH18 were developed from RAPDs OB12 350 and OAH1 ${ }_{1100}$, respectively, and a genetic map including the resistance gene and markers SB12, OY17 ${ }_{1100}$, SAH18, SW12 and SI19 was made using a $\mathrm{F}_{2}$ segregating population of 72 individuals derived from the cross 'Andecha' $\times$ 'A493'.
\end{abstract}

\section{Introduction}

Anthracnose, caused by the fungus Colletotrichum lindemuthianum, is one of the most widespread and economically important diseases of common bean (Phaseolus vulgaris). Anthracnose is especially harmful in tropical and subtropical areas, where common bean is the major source of protein for human consumption, but it is not restricted to such areas. It can also cause considerable yield losses in temperate areas, as in Northern Spain, where appreciated dry bean landraces are grown.

High genetic variability of $C$. lindemuthianum has been observed in different parts of the world (Menezes \& Dianese, 1988; Pastor-Corrales \& Tu, 1989; Balardin et al., 1997). Currently, the different $C$. lindemuthi- anum races are characterized based on phenotypic reaction on a universal set of 12 differential cultivars and named based on a binary nomenclature system (PastorCorrales, 1991). Up to 10 genes (Co- 1 to $\mathrm{Co}-10)$ that confer dominant resistance (except $\mathrm{co}-8$ ) to different sets of pathogenic races have been described. A number of allelism tests have been carried out indicating that the six genes, $\mathrm{Co}-1$ to $\mathrm{Co}-6$, are located at independent loci. Co- 1 (Burkholder, 1918) was first described as present in the differential cultivar 'Michigan Dark Red Kidney' (Young \& Kelly, 1997), and two alleles of this gene, conferring resistance to different pathotype spectra, are present in the differential cultivars 'Perry Marrow' and 'Kaboon' (Melotto \& Kelly, 2000). Co2 is present in 'Cornell 49242' (Mastenbroek, 1960), 
and has been located on linkage group B11 (Freyre et al., 1998). Co-3 is present in the differential cultivar 'Mexico 222' (Bannerot et al., 1971) and, as a second allelic form, in cultivar 'Mexico 227' (Fouilloux, 1976). Three different alleles of $C o-4$ have been reported as being present in the differential cultivars ' $T O$ ' (Fouilloux, 1976), 'G2333' (Young et al., 1998) and 'PI 207262' (Alzate-Marin et al., 2001). Co-5 is present in differential cultivars 'TU' (Fouilloux, 1976) and ' $G$ 2333' (Young \& Kelly, 1996; Young et al., 1998). Finally, Co-6 is present in the differential cultivar 'AB 136' (Young \& Kelly, 1996).

The characterization of anthracnose resistance genes $\mathrm{Co}-7$ to $\mathrm{Co}-10$ has been less extensive. $\mathrm{Co}-7$ was the name proposed by Young et al. (1998) for a third resistance gene that, together with $\mathrm{Co}-4$ and $\mathrm{Co}-5$, is present in the differential cultivar ' $\mathrm{G} 2333$ '. The presence in 'AB 136' of a resistance recessive gene, co- 8 , was proposed by Alzate-Marin et al. (1997) in order to explain a $13: 3$ segregation in a cross involving this differential cultivar. Geffroy et al. (1999) proposed the name $\mathrm{Co}-9$ for the anthracnose resistance gene present in the breeding line 'BAT 93' that, together with the resistance specifities $C o-y$ and $C o-z$ carried by the landrace 'Jalo EEP558', constitute part of a resistance gene cluster located in linkage group B4. Finally, Co10 has been recently proposed by Alzate-Marin et al. (2003) as a new anthracnose resistance gene, present in cultivar 'Ouro Negro', that segregates independently of Co-1, Co-2, Co-3, Co-4, Co-5 and Co-6.

In the present work, allelism tests and molecular marker analyses were combined in order to characterize the anthracnose resistance genes that, proceeding from the germplasm lines 'A321' and 'A493', were introduced in a dry bean landrace by means of backcross breeding programs. Evidence indicating that $\mathrm{Co}$ 9 was the gene introduced in both cases is presented. The allelic relationships between previously known anthracnose resistance genes and $\mathrm{Co}-9$ were established, and two tightly linked SCAR markers that discriminate among genotypes carrying this gene, were developed.

\section{Materials and methods}

\section{Plant material}

Genetic resistance to anthracnose was introduced into the cultivar 'Andecha' using germplasm lines 'A321' and 'A493' as resistance donors and 'Andecha' as the recurrent parent in two parallel backcross breeding programs developed in SERIDA (Villaviciosa, Asturias). 'Andecha' is a very large white seeded cultivar proceeding from a selection of Asturian landraces. Germplasm lines 'A321' ('BAT561'//'G7474'/'Guanajuato31') and 'A493' ('Alubia'/'BAT93') proceeded from CIAT (Cali, Colombia). The observed phenotypic ratios in the $F_{2}$ progeny of 'Andecha' $\times$ 'A321' and in the $F_{2: 3}$ progeny of 'Andecha' $\times$ 'A493' (Table 1) indicated that two independent dominant genes for the resistance to race 38 of anthracnose are present in 'A321' whereas a single dominant gene is present in 'A493'. After six backcross generations, breeding lines 'A1231' and 'A1220' were obtained, each one carrying a single resistance gene proceeding from 'A321' and 'A493', respectively.

In order to test for allelism, resistance to anthracnose was determined in $\mathrm{F}_{2}$ plants proceeding from different crosses involving cultivars and/or lines 'Andecha', 'A493', 'A321', 'A1220', 'A1231', 'BAT93', 'Cornell 49242', 'Mexico 222', 'TO', 'TU', 'AB 136' and 'PI 207262'.

To test the possible co-segregation between resistances to races 6 and 38 introduced in the breeding line 'A1220', resistance tests using these two races were performed in $20 \mathrm{~F}_{2: 3}$ families proceeding from a cross between this breeding line and the landrace 'Cimera', susceptible to both races.

Table 1. Observed ratio of the progenies of crosses 'Andecha' $\times$ 'A321' $\left(\mathrm{F}_{2}\right)$ and 'Andecha' $\times$ 'A493' $\left(\mathrm{F}_{2: 3}\right)$ for the reaction to race 38 of Colletotrichum lindemuthianum

\begin{tabular}{|c|c|c|c|c|c|c|c|c|}
\hline \multicolumn{4}{|c|}{ Population Andecha $\times$ A321 } & \multicolumn{5}{|c|}{ Population Andecha $\times$ A493 } \\
\hline \multicolumn{2}{|c|}{ Number of $F_{2}$ plants } & \multirow[b]{2}{*}{$\chi^{2 \mathrm{a}}$} & \multirow[b]{2}{*}{ Probability } & \multicolumn{3}{|c|}{ Number of $F_{2: 3}$ plants } & \multirow[b]{2}{*}{$\chi^{2 b}$} & \multirow[b]{2}{*}{ Probability } \\
\hline $\mathrm{R}-$ & $\mathrm{rr}$ & & & $\mathrm{RR}$ & $\mathrm{Rr}$ & $\mathrm{rr}$ & & \\
\hline 258 & 17 & 0.002 & 0.96 & 20 & 32 & 18 & 0.628 & 0.73 \\
\hline
\end{tabular}

${ }^{a}$ Value for a 15:1 (resistant, R-; susceptible, rr) expected ratio.

${ }^{\mathrm{b}}$ Value for a 1:2:1 (homozygous resistant, RR; heterozygous resistant, Rr; susceptible, rr) expected ratio. 
The $\mathrm{F}_{2}$ and $\mathrm{F}_{2: 3}$ families proceeding from the cross 'Andecha' $\times$ 'A493' were also used to test for putative linkages between RAPD and SCAR markers and the resistance gene present in 'A493'.

The amplification products of RAPD OY $17_{1100}$ and SCARs SB12 (Méndez de Vigo et al., 2002), SW12 (Miklas et al., 2000) and SAH18 (present work) were analyzed in 'Andecha', 'A493', 'A321', 'A1220', 'A1231', in the anthracnose differential cultivars: 'Michelite', 'Michigan Dark Red Kidney', 'Perry Marrow', 'Cornell 49242', 'Widusa', 'Kaboon', 'Mexico 222', 'PI 207262', 'TO', 'TU', 'AB 136' and 'G 2333', and in other characterized resistance sources: 'BAT 93', 'Jalo EEP558', 'Catrachita', 'SEL 1308' and 'SEL 1360 '.

\section{Fungal material and pathogenicity tests}

Races 3, 6, 38, 102 and 787 of $C$. lindemuthianum were used in this study. These are the most common races found in Northern Spain (Ferreira et al., 1998). Monosporic cultures, maintained in stocks of fungus-colonized filter paper were first tested against the twelve anthracnose differential cultivars (Pastor-Corrales, 1991) to confirm their identity. The two donors, 'A321' and 'A493', and the corresponding breeding lines 'A1231' and 'A1220' were resistant to all races. Race 38 was chosen to determine the resistance in all allelism and linkage tests. The inoculations were carried out on 8-10 days old seedlings in a climate chamber. The seedlings were sprayed with an aqueous conidial suspension containing $10^{6}$ spores per $\mathrm{ml}$ and maintained at $20-22{ }^{\circ} \mathrm{C}, 95-100 \%$ humidity and $12 \mathrm{~h}$ photoperiod. The responses of the plants were evaluated after 7-9 days. The reaction of the bean materials used in this work to $C$. lindemuthianum races $3,6,38$, 102 and 787 are shown in Table 2.

\section{RAPD analyses}

Genomic DNA was isolated from young leaves using the Nucleon Phytopure Kit (Amersham Pharmacia Biotech). In order to test for putative linkages between molecular markers and the resistance genes present in the two breeding lines, the amplification patterns of 'Andecha', 'A321', 'A493', 'A1231' and 'A1220' were screened using 373 random primers (Operon Technologies, Alameda, CA). PCRs were processed in a $25-\mu 1$ total reaction mixture containing $30 \mathrm{ng}$ of total DNA, $100 \mathrm{mM}$ Tris- $\mathrm{HCl}, 100 \mathrm{mM} \mathrm{KCl} \mathrm{pH} \mathrm{8.3,} 4 \mathrm{mM} \mathrm{MgCl}_{2}$, $0.2 \mathrm{mM}$ of each dNTP (Roche), $0.2 \mu \mathrm{M}$ of primer and
Table 2. Reaction of the bean materials used in this work to Colletotrichum lindemuthianum pathotypes 3, 6, 38, 102 and 787, present in Northern Spain

\begin{tabular}{llllll}
\hline & \multicolumn{5}{c}{ Pathotype } \\
\cline { 2 - 6 } Cultivar/line & 3 & 6 & 38 & 102 & 787 \\
\hline Cornell 49242 & $\mathrm{R}$ & $\mathrm{R}$ & $\mathrm{R}$ & $\mathrm{R}$ & $\mathrm{R}$ \\
Mexico 222 & $\mathrm{R}$ & $\mathrm{R}$ & $\mathrm{R}$ & $\mathrm{S}$ & $\mathrm{R}$ \\
PI 207262 & $\mathrm{R}$ & $\mathrm{R}$ & $\mathrm{R}$ & $\mathrm{R}$ & $\mathrm{R}$ \\
To & $\mathrm{R}$ & $\mathrm{R}$ & $\mathrm{R}$ & $\mathrm{R}$ & $\mathrm{S}^{*}$ \\
Tu & $\mathrm{R}$ & $\mathrm{R}$ & $\mathrm{R}$ & $\mathrm{R}$ & $\mathrm{S}$ \\
AB 136 & $\mathrm{R}$ & $\mathrm{R}$ & $\mathrm{R}$ & $\mathrm{R}$ & $\mathrm{R}$ \\
BAT 93 & $\mathrm{R}$ & $\mathrm{R}$ & $\mathrm{R}$ & $\mathrm{R}$ & $\mathrm{R}$ \\
A252 & $\mathrm{R}$ & $\mathrm{R}$ & $\mathrm{R}$ & $\mathrm{R}$ & $\mathrm{R}$ \\
A321 & $\mathrm{R}$ & $\mathrm{R}$ & $\mathrm{R}$ & $\mathrm{R}$ & $\mathrm{R}$ \\
A493 & $\mathrm{R}$ & $\mathrm{R}$ & $\mathrm{R}$ & $\mathrm{R}$ & $\mathrm{R}$ \\
Andecha & $\mathrm{R} *$ & $\mathrm{~S}$ & $\mathrm{~S}$ & $\mathrm{R} *$ & $\mathrm{R}$ \\
A1220 & $\mathrm{R}$ & $\mathrm{R}$ & $\mathrm{R}$ & $\mathrm{R}$ & $\mathrm{R}$ \\
A1231 & $\mathrm{R}$ & $\mathrm{R}$ & $\mathrm{R}$ & $\mathrm{R}$ & $\mathrm{R}$ \\
\hline
\end{tabular}

$\mathrm{R}$, resistant, no lesions, or lesions affecting less than $5 \%$ of the inoculated leave surfaces; $\mathrm{R}^{*}$, moderately resistant, lesions affecting $5-25 \%$ of the inoculated leave surfaces; $\mathrm{S}^{*}$, susceptible, lesions affecting $25-80 \%$ of the inoculated leave surfaces; $\mathrm{S}$, highly susceptible, necrosis affecting more than $80 \%$ of the inoculated leave surfaces.

1.25 U Stoffel DNA polymerase (Perkin-Elmer). Amplification reactions were performed in a PCR System 9600 (Perkin-Elmer) programmed as follows: $94^{\circ} \mathrm{C}$ for $5 \mathrm{~min}, 35$ cycles of $94^{\circ} \mathrm{C}$ for $35 \mathrm{~s}, 40^{\circ} \mathrm{C}$ for $2 \mathrm{~min}$ and $72^{\circ} \mathrm{C}$ for $2 \mathrm{~min}$ with a ramp of $1 \mathrm{~s}$ per cycle, followed by a final step of $72{ }^{\circ} \mathrm{C}$ for $7 \mathrm{~min}$.

\section{SCAR analyses}

Amplification of SCAR SI19 was carried out as described by Melotto \& Kelly (1998). The amplification of the SCAR SW12 (Miklas et al., 2000) was carried out in a $25 \mu \mathrm{l}$ solution containing $25 \mathrm{ng}$ of DNA, $100 \mathrm{mM}$ Tris- $\mathrm{HCl}, 100 \mathrm{mM} \mathrm{KCl} \mathrm{pH} \mathrm{8.3,} 5 \mathrm{mM} \mathrm{MgCl}_{2}, 0.2 \mathrm{mM}$ of each dNTP (Roche), $0.2 \mu \mathrm{M}$ of each primer and $1.25 \mathrm{U}$ of Stoffel fragment DNA polymerase (PerkinElmer). Amplification was performed in a 9600 PerkinElmer DNA thermal cycler programmed as follows: $94^{\circ} \mathrm{C}$ for $1 \mathrm{~min}, 30$ cycles of $94^{\circ} \mathrm{C}$ for $30 \mathrm{~s}, 70^{\circ} \mathrm{C}$ for $30 \mathrm{~s}$ and $72^{\circ} \mathrm{C}$ for $1 \mathrm{~min}$, followed by $5 \mathrm{~min}$ extension at $72^{\circ} \mathrm{C}$. The DNA fragments corresponding to RAPDs $\mathrm{OB} 12_{350}$ and $\mathrm{OAH} 18_{1100}$, linked to the resistance gene present in 'A1220', were purified using the GFX PCR DNA and Gel Band Purification Kit (Amersham 
Biosciences) and cloned using the pGEM $^{\circledR}-T$ Easy Vector System II (Promega). Double-stranded sequencing of cloned DNA fragments was performed with the ABI PRISM Big Dye Terminator kit in a PCR System 9600 thermal cycler (Perkin-Elmer) and analyzed in a 310 Genetic Analyzer (Applied Biosystems) automated sequencer. The amplification of SCARs SB12 and SAH18 was carried out in a $25 \mu \mathrm{l}$ solution containing $25 \mathrm{ng}$ of DNA, $100 \mathrm{mM}$ Tris- $\mathrm{HCl}, 100 \mathrm{mM}$ $\mathrm{KCl} \mathrm{pH} \mathrm{8.3,} 5 \mathrm{mM} \mathrm{MgCl}_{2}$ (SB12) or $4 \mathrm{mM} \mathrm{MgCl}_{2}$ (SAH18), $0.2 \mathrm{mM}$ of each dNTP (Roche), $0.2 \mu \mathrm{M}$ of each primer and $1.25 \mathrm{U}$ of Stoffel fragment DNA polymerase (Perkin-Elmer). Amplifications were performed in a 9600 Perkin-Elmer DNA thermal cycler programmed as follows: $94^{\circ} \mathrm{C}$ for $2 \mathrm{~min}, 35$ cycles of $94^{\circ} \mathrm{C}$ for $1 \mathrm{~min}, 68^{\circ} \mathrm{C}$ for $1 \mathrm{~min}$ and $72^{\circ} \mathrm{C}$ for $1 \mathrm{~min}$, followed by $7 \mathrm{~min}$ extension at $72{ }^{\circ} \mathrm{C}$, for SB12; and 34 cycles of $94^{\circ} \mathrm{C}$ for $10 \mathrm{~s}, 69^{\circ} \mathrm{C}$ for $40 \mathrm{~s}$ and $72^{\circ} \mathrm{C}$ for 2 min, followed by 5 min extension at $72{ }^{\circ} \mathrm{C}$, for SAH18.

\section{Linkage analysis}

Simple inheritance of the disease phenotype and the RAPD and SCAR markers was confirmed using Chi- square tests. Linkage analyses were performed using the program MAPMAKER (Lander et al., 1987). Distances between markers were presented in centimorgans (cM), as calculated using Kosambi's function by the computer program.

\section{Results}

\section{Allelism tests}

The segregation ratios obtained in the selection for resistance to anthracnose carried out during the six generations of the backcross breeding program and in subsequent selfings in the development of lines 'A1220' and 'A1231' (data not shown) indicated that each line carried a single dominant gene for resistance to race 38 . Allelism tests for characterization of resistance genes in lines 'A1220' and 'A1231' are shown in Table 3. No segregation was observed in the $F_{2}$ population derived from the cross 'A 1220 ' $\times$ 'A 1231 ', suggesting that the dominant genes in these two lines are located at the same locus. No segregation was observed in the $F_{2}$ populations derived from crosses 'A1220' $\times$ 'Mexico 222', 'A1220' × 'PI 207262', 'A1220' × 'BAT 93',

Table 3. F2 segregations from $\mathrm{R} \times \mathrm{R}$ and $\mathrm{S} \times \mathrm{R}$ crosses for the genetic characterization of the resistance to race 38 of $C$. lindemuthianum in lines 'A1220' and 'A1231'

\begin{tabular}{|c|c|c|c|c|c|c|c|c|}
\hline \multirow[b]{2}{*}{$\mathrm{F}_{2}$ population } & \multirow[b]{2}{*}{ Reaction $^{\mathrm{a}}$} & \multicolumn{2}{|c|}{ Observed frequencies } & \multicolumn{3}{|c|}{ Expected frequencies } & \multirow[b]{2}{*}{$\chi^{2}$} & \multirow[b]{2}{*}{ Probability } \\
\hline & & $\mathrm{R}$ & $\mathrm{S}$ & Ratio & $\mathrm{R}$ & $\mathrm{S}$ & & \\
\hline $\mathrm{A} 1220 \times \mathrm{A} 1231$ & $\mathrm{R} \times \mathrm{R}$ & 171 & 0 & $15: 1$ & 160.3 & 10.7 & 11.400 & 0.001 \\
\hline A1220 × Mexico 222 & $\mathrm{R} \times \mathrm{R}$ & 115 & 0 & $15: 1$ & 107.8 & 7.2 & 7.667 & 0.006 \\
\hline A1220 × PI 207262 & $\mathrm{R} \times \mathrm{R}$ & 108 & 0 & $15: 1$ & 101.3 & 6.8 & 7.200 & 0.007 \\
\hline A1220 × BAT 93 & $\mathrm{R} \times \mathrm{R}$ & 213 & 0 & $15: 1$ & 199.7 & 13.3 & 14.200 & 0.000 \\
\hline A1220 × Cornell 49242 & $\mathrm{R} \times \mathrm{R}$ & 98 & 6 & $15: 1$ & 97.5 & 6.5 & 0.041 & 0.839 \\
\hline $\mathrm{A} 1220 \times \mathrm{AB} 136$ & $\mathrm{R} \times \mathrm{R}$ & 105 & 7 & $15: 1$ & 105.0 & 7.0 & 0.000 & 1.000 \\
\hline $\mathrm{A} 1220 \times \mathrm{TU}$ & $\mathrm{R} \times \mathrm{R}$ & 116 & 16 & $15: 1$ & 123.8 & 8.3 & 7.766 & 0.005 \\
\hline A1231 $\times$ Mexico 222 & $\mathrm{R} \times \mathrm{R}$ & 246 & 0 & $15: 1$ & 230.6 & 15.4 & 16.400 & 0.000 \\
\hline A1231 × PI 207262 & $\mathrm{R} \times \mathrm{R}$ & 222 & 0 & $15: 1$ & 208.1 & 13.9 & 14.800 & 0.000 \\
\hline A1231 × BAT 93 & $\mathrm{R} \times \mathrm{R}$ & 95 & 0 & $15: 1$ & 89.1 & 5.9 & 6.333 & 0.012 \\
\hline A1231 × Cornell 49242 & $\mathrm{R} \times \mathrm{R}$ & 208 & 9 & $15: 1$ & 203.4 & 13.6 & 1.637 & 0.201 \\
\hline $\mathrm{A} 1231 \times \mathrm{TO}$ & $\mathrm{R} \times \mathrm{R}$ & 102 & 11 & $15: 1$ & 105.9 & 7.1 & 2.342 & 0.126 \\
\hline $\mathrm{A} 1231 \times \mathrm{AB} 136$ & $\mathrm{R} \times \mathrm{R}$ & 236 & 13 & $15: 1$ & 233.4 & 15.6 & 0.450 & 0.502 \\
\hline $\mathrm{A} 1231 \times \mathrm{TU}$ & $\mathrm{R} \times \mathrm{R}$ & 102 & 14 & $15: 1$ & 108.8 & 7.3 & 6.703 & 0.010 \\
\hline Andecha $\times$ Mexico 222 & $\mathrm{~S} \times \mathrm{R}$ & 76 & 20 & $3: 1$ & 72.0 & 24.0 & 0.889 & 0.346 \\
\hline Andecha $\times$ PI 207262 & $\mathrm{~S} \times \mathrm{R}$ & 197 & 54 & $3: 1$ & 188.3 & 62.8 & 1.627 & 0.202 \\
\hline Andecha $\times$ BAT 93 & $\mathrm{~S} \times \mathrm{R}$ & 80 & 22 & $3: 1$ & 76.5 & 25.5 & 0.641 & 0.424 \\
\hline PI $207262 \times$ Mexico 222 & $\mathrm{R} \times \mathrm{R}$ & 159 & 0 & $15: 1$ & 149.1 & 9.9 & 10.600 & 0.001 \\
\hline
\end{tabular}

${ }^{\mathrm{a}} \mathrm{R}$, resistant reaction and $\mathrm{S}$, susceptible reaction to race 38 . 
'A1231' × 'Mexico 222', 'A1231' × 'PI 207262' and 'A1231' $\times$ 'BAT93', indicating that the dominant resistance gene in lines 'A1220' and 'A1231' is located at the same locus as the resistance genes in 'Mexico 222', 'PI 207262' and 'BAT 93'. The 3:1 (R-:rr) ratio observed in the $\mathrm{F}_{2}$ populations derived from susceptible $\times$ resistant crosses 'Andecha' $\times$ 'Mexico 222', 'Andecha' $\times$ 'PI 207262', and 'Andecha' $\times$ 'BAT 93', and the lack of segregation in the $F_{2}$ from the cross 'PI 207262' × 'Mexico 222' support the assumption that the same locus provides resistance to race 38 in all these genotypes.

In the $\mathrm{F}_{2}$ populations derived from crosses between 'Cornell 49242', 'TO', or 'AB 136' and 'A1220' and 'A1231', the Chi-square tests supports a good fit to the 15:1 expected ratio of resistant to susceptible plants. This indicates that the single dominant gene in lines 'A1220' and 'A1231' segregates independently from the genes conditioning resistance in 'Cornell 49242' (Co-2), 'TO' (Co-4), and 'AB 136' (Co-6). In the two $\mathrm{F}_{2}$ populations in which ' $\mathrm{TU}$ ' was involved, a significant excess of susceptible plants was observed when compared to the expected 15:1 ratio. Nevertheless, the occurrence of such susceptible plants indicates that the resistance gene carried by ' $\mathrm{TU}$ ' $(\mathrm{Co}-5)$ is different from the gene in 'A1220' and 'A1231'.

\section{Co-segregation of resistance specificities to races 6 and 38}

Resistance tests using races 6 and 38 were performed in $20 \mathrm{~F}_{2: 3}$ families proceeding from a cross between the breeding line 'A1220' and the landrace 'Cimera', susceptible to both races. A co-segregation between these two resistance specificities was observed: $\mathrm{six}_{2: 3}$ families with all the individuals resistant to both races; nine $\mathrm{F}_{2: 3}$ families showing segregation of individuals resistant and susceptible to both races; and five $\mathrm{F}_{2: 3}$ families with all the individuals susceptible to both races. These results indicate that the gene conferring resistance to race 38 in the breeding line 'A 1220 ' also contributes to resistance to race 6 .

\section{Molecular-marker analyses}

To identify molecular markers linked to the resistance gene present in lines 'A1220' and 'A1231', the amplification products of 374 decamer primers (Operon Technologies) present in lines 'Andecha', 'A493', 'A321', 'A1220' and 'A1231' were compared. Twenty different SCAR markers were also included in this comparison. Both 'A1220' and 'A1231' conserved RAPD markers OB12 350 , OAH1 $18_{100}$, OI19 460 and OY17 1100 and SCAR markers SI19 (proceeding from OI19 460 , Haley et al., 1994; Melotto \& Kelly, 1998) and SW12 (Miklas et al., 2000) from their corresponding donor parents, 'A493' and 'A321'. In addition, 'A1220' conserved RAPD markers OH19 ${ }_{425}$, and OZ13 325 from its parental resistance donor 'A493'. $\mathrm{A} \mathrm{F}_{2}$ population of 72 individuals derived from the cross 'Andecha' $\times$ 'A493' was used to test the linkage of these markers to the resistance gene (Table 4). Markers OB12 ${ }_{350}$, OAH1 ${ }_{1100}$, OY $17_{1100}$, SI19 (co-segregating with OI19460) and SW12 were significantly linked to the resistance gene,

Table 4. Chi-square $\left(\chi^{2}\right)$ and linkage analysis of markers OB12350, OAH1 $18_{1100}, \mathrm{OH} 19_{425}, \mathrm{SI}_{19} 9_{460}, \mathrm{OZ}_{13} 3_{325}, \mathrm{OY} 17_{1100}$ and $\mathrm{SW}_{12} 475$ and the resistance to pathotype 38 of Colletotrichum lindemuthianum in a $\mathrm{F}_{2}$ population derived from the cross 'Andecha' $\times$ 'A493'

\begin{tabular}{|c|c|c|c|c|c|}
\hline Marker & Expected ratio $^{\mathrm{a}}$ & Observed frequency & $\chi^{2}$ & $p$ & $\mathrm{cM}^{\mathrm{b}}$ \\
\hline OB12350 & $3: 6: 3: 1: 2: 1$ & 20:27:0:0:4:18 & 52.96 & 0.00 & 3.4 \\
\hline OAH $18_{1100}$ & $3: 6: 3: 1: 2: 1$ & $20: 29: 1: 0: 3: 16$ & 50.66 & 0.00 & 4.7 \\
\hline $\mathrm{OH} 19_{425}$ & $3: 6: 3: 1: 2: 1$ & $13: 23: 15: 7: 8: 2$ & 2.67 & 0.26 & Unlinked \\
\hline SI19460 & $3: 6: 3: 1: 2: 1$ & $4: 30: 17: 16: 3: 1$ & 37.04 & 0.00 & 12.6 \\
\hline $\mathrm{OZ}_{13} 3_{325}$ & $3: 6: 3: 1: 2: 1$ & $14: 24: 17: 5: 8: 1$ & 3.28 & 0.19 & Unlinked \\
\hline OY $17_{1100}$ & $3: 6: 3: 1: 2: 1$ & 20:29:0:0:2:18 & 59.91 & 0.00 & 1.6 \\
\hline SW12 $475 / 575$ & $1: 2: 1: 2: 4: 2: 1: 2: 1$ & $17: 1: 0: 2: 30: 0: 0: 1: 17$ & 114.13 & 0.00 & 2.2 \\
\hline
\end{tabular}

\footnotetext{
${ }^{a}$ Marker analyses were performed using DNA from $\mathrm{F}_{2}$ plants and the evaluation of the resistance was carried out in the corresponding $\mathrm{F}_{2: 3}$ families. The expected ratios are based on 1:2:1 genotypic segregation ratio for the resistance gene and marker SW 12 475/575 (codominant inheritance), and 3:1 ratio for the remaining markers (dominant inheritance). ${ }^{\mathrm{b}}$ Distances $(\mathrm{cM})$ between each marker and the resistance gene were calculated using MAPMAKER software (Kosambi function).
} 
Table 5. SCAR primer sequences derived from the RAPD markers $\mathrm{OB} 12_{350}$ and $\mathrm{OAH} 18_{1100}$

\begin{tabular}{|c|c|c|}
\hline SCAR marker & Primer & Sequence $^{\mathrm{a}}$ \\
\hline \multirow[t]{2}{*}{ SB12 } & SB12F & 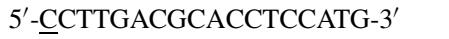 \\
\hline & SB12R & $5^{\prime}$-TTGACGCATGGGTTGGCC-3' \\
\hline \multirow[t]{2}{*}{ SAH18 } & SAH18F & 5'-GGGCTAGTCAGACTGATTCT-3' \\
\hline & SAH18R & $5^{\prime}$-GGGCTAGTCAAATCAAAGGC-3' \\
\hline
\end{tabular}

${ }^{\mathrm{a}}$ Underlined sequences correspond to the original RAPD markers.

whereas markers $\mathrm{OH} 19_{425}$, and $\mathrm{OZ} 13_{325}$ segregated independently from the resistance gene and were significantly linked to each other at a distance of $12.6 \mathrm{cM}$ (data not shown).

The DNA fragments corresponding to RAPDs OB12 350 and OAH18 1100 were purified, cloned, sequenced and converted to the SCAR markers SB12 and SAH18. The primer sequences for these SCARs are shown in Table 5. The SCAR markers SB12 and SAH18 amplified single DNA fragments of the expected sizes, 350 and $1100 \mathrm{bp}$, respectively. Cosegregation between these SCARs and their corresponding RAPDs, OB12 350 and OAH18 1100 , was observed in the 'Andecha' $\times$ 'A493' $F_{2}$ population.

A genetic map of the resistance gene cluster on B4 and markers SB12, OY17 1100, SAH18, SW12 and SI19 is shown in Figure 1.

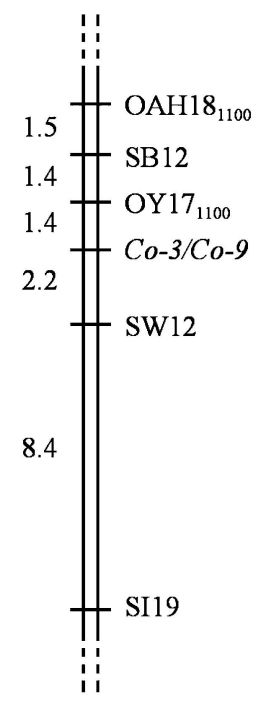

Figure 1. Relative positions of markers OAH18 $1100, \mathrm{SB} 12_{350}$, OY $17_{1100}$, SW12 and SI19 460 and the anthracnose resistance gene cluster $\mathrm{Co}$-3/Co-9. Map distances, on the left, are expressed in centiMorgans, estimated using the Kosambi map function.
The amplification patterns of markers SB12, OY $17_{1100}$, SAH18 and SW12 in 22 genotypes including the 12 differential cultivars, and other frequently used resistance sources are shown in Figure 2 and summarized in Table 6 . The SB12 amplification band (Figure 2a) was only present in breeding lines 'A1220' and 'A1231', in their corresponding resistance donors 'A493' and 'A321', in 'BAT 93' and in 'PI 207262'. The OY $17_{1100}$ RAPD band (Figure $2 b$ ) was also present only in genotypes 'A1220', 'A1231', 'A493', 'A321', 'BAT 93' and 'PI 207262', although a weaker amplification of this band was observed in ' $\mathrm{G} 2333$ ' and 'SEL 1308'. The SAH18 amplification band (Figure 2c) was present in a larger number of materials: 'Perry Marrow', 'Mexico 222', 'PI 207262', 'TU', 'AB 136', 'SEL 1308', 'SEL 1360', 'Catrachita', 'BAT 93', 'A321', 'A493', 'A1231', 'A1220'. The SW12 SCAR primers produced six different amplification phenotypes in the 22 genotypes analyzed (Figure 2d): no amplification ('Michelite', 'MDRK', 'Widusa', 'AB136', 'Catrachita' and 'Jalo EEP558'); one single band of $700 \mathrm{bp}$ ('Cornell 49242', 'Kaboon', 'TO', 'SEL 1308', 'A321' and 'A1231'); two bands of 700 and 600 bp ('Perry Marrow', 'TU' and 'Andecha'); two bands of 700 and 425 bp ('Mexico 222'); three bands of 700, 600 and 575 bp ('G 2333' and 'SEL 1360'); and three bands of 700, 600 and 475 bp ('PI 207262', 'BAT 93', 'A493' and 'A1220').

\section{Discussion}

The results obtained in the allelism tests (Table 3) indicate that the resistance to race 38 of anthracnose in genotypes 'A1220', 'A1231', 'BAT 93', 'PI 207262' and 'Mexico 222' is determined by very close linked genes or by dominant resistance alleles of the same single locus. The presence of an identical resistance gene in lines 'A1220', 'BAT 93' and 'PI 207262' can be explained by their genealogical relationships. Breeding line 'A1220' was obtained after six backcross generations using germplasm line 'A493' ('Alubia'/'BAT 93') as resistance donor. Line 'BAT 93' was derived from a four-way cross that included the differential cultivar 'PI 207262' (synonymous with 'Tlalnepantla 64') as a parent. The resistance in line 'A1231' proceeds from germplasm line 'A321' ('BAT 561'//'G 7474 '/'Guanajuato 31'). 'Tlalnepantla 64' might be related to 'Guanajuato 31', as both accessions come from the humid highlands of Mexico (Singh, personal communication). 'Mexico 222' is a Mexican germplasm 


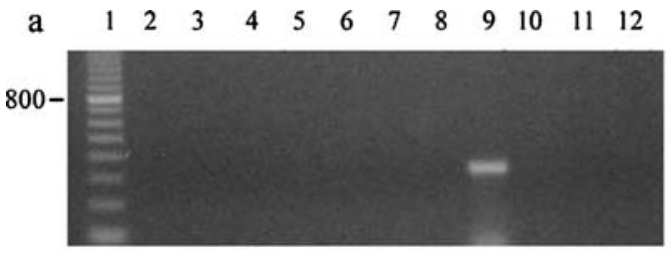

$\begin{array}{lllllllllllll}\text { b } & 1 & 2 & 3 & 4 & 5 & 6 & 7 & 8 & 9 & 10 & 11 & 12\end{array}$
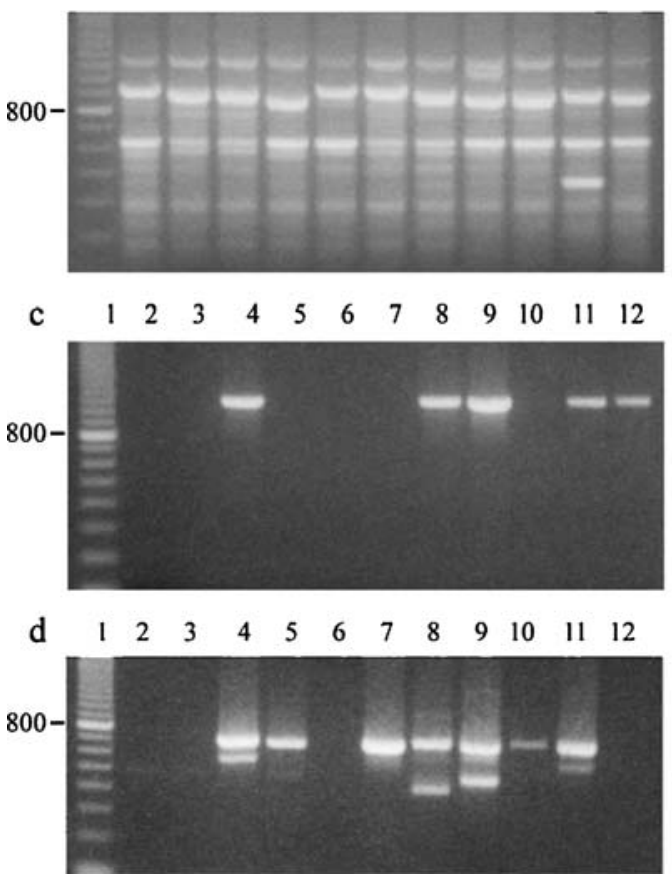

$\begin{array}{llllllllllll}13 & 14 & 15 & 16 & 17 & 18 & 19 & 20 & 21 & 22 & 23 & 24\end{array}$

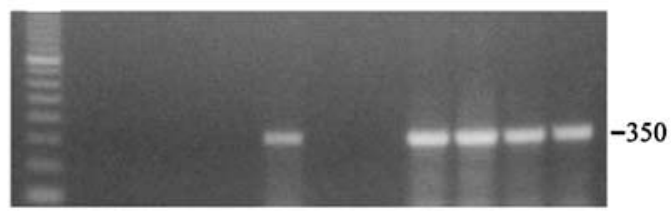

$\begin{array}{llllllllllll}13 & 14 & 15 & 16 & 17 & 18 & 19 & 20 & 21 & 22 & 23 & 24\end{array}$

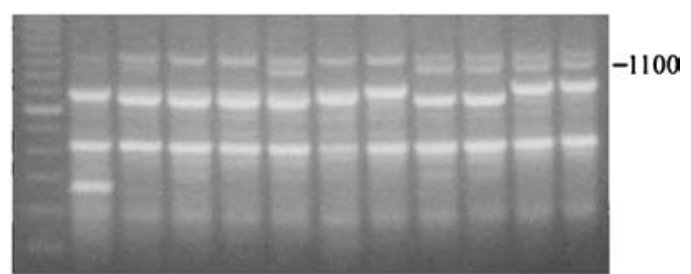

$\begin{array}{llllllllllll}13 & 14 & 15 & 16 & 17 & 18 & 19 & 20 & 21 & 22 & 23 & 24\end{array}$

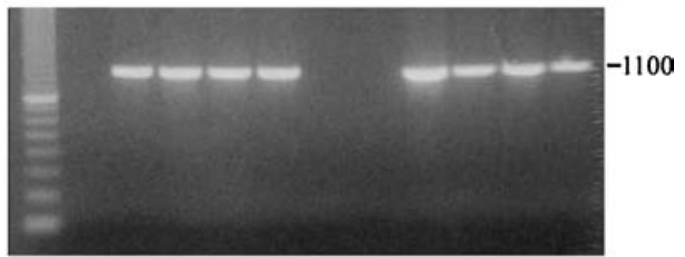

$\begin{array}{llllllllllll}13 & 14 & 15 & 16 & 17 & 18 & 19 & 20 & 21 & 22 & 23 & 24\end{array}$

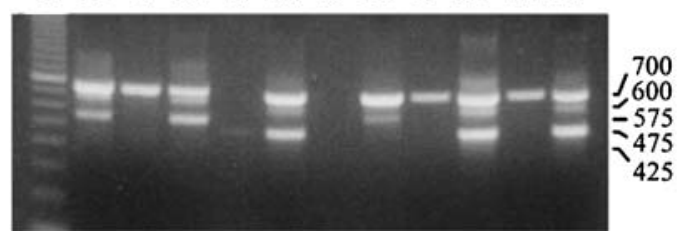

Figure 2. (a-d) DNA amplification patterns of 22 bean materials using (a) the SB12 SCAR marker, (b) the OY17 1100 RAPD marker, (c) the SAH18 SCAR marker, (d) the SW12 SCAR marker. Lane (1) 100-bp DNA ladder, lane (2) 'Michelite', lane (3) 'MDRK', lane (4) 'Perry Marrow', lane (5) 'Cornell 49242', lane (6) 'Widusa', lane (7) 'Kaboon', lane (8) ‘Mexico 222', lane (9) 'PI 207262', lane (10) ‘TO', lane (11) 'TU', lane (12) 'AB136', lane (13) 100-bp DNA ladder, lane (14) 'G 2333', lane (15) 'SEL 1308', lane (16) 'SEL 1360', lane (17) 'Catrachita', lane (18) 'BAT 93', lane (19) 'Jalo EEP558', lane (20) 'Andecha', lane (21) 'A321', lane (22) 'A493', lane (23) 'A1231', lane (24) 'A1220'.

line used as differential cultivar, which carries the gene Co-3 (formerly named Mexique 1; Bannerot et al., 1971). The results obtained in the present study (Table 3) agree with those of Bannerot et al. (1971), Fouilloux (1976), Young \& Kelly (1996) and Young et al. (1998) indicating that the gene present in 'Mexico 222' (Co-3) is independent from $\mathrm{Co}-2$ (present in 'Cornell 49242'), Co-4 ('TO' and 'SEL 1308'), Co-5 ('TU' and 'SEL 1360') and Co-6 ('AB 136' and 'Catrachita').

On the other hand, the resistance gene analyzed in the present study is linked to molecular markers SI19, OY 17 1100 and SW12 (Figure 1), which have been previously mapped to linkage group B4 (Melotto \& Kelly, 1998; Miklas et al., 2000, 2002). Geffroy et al. (1999) proposed the name $\mathrm{Co}-9$ for the anthracnose resistance gene present in the breeding line 'BAT 93', and the names $C o-y$ and $C o-z$ for resistance specificities carried by the landrace 'Jalo EEP558'. These two bean genotypes are the parents of recombinant inbred lines (RILs) that were used in the development of a core linkage map of common bean (Freyre et al., 1998). The molecular and segregation analyses carried out by Geffroy et al. (1999) indicated that $\mathrm{Co}-9$, and $\mathrm{Co}-\mathrm{y} / \mathrm{Co}$ $z$ are alleles at a complex locus formed by an $\mathrm{R}$ gene cluster located on B4. Based on its specific pathotype spectra, $\mathrm{Co}-9$ was considered different from previously described genes ( $\mathrm{Co}-1$ to $\mathrm{Co}-8)$, but allelism tests with the corresponding differential cultivars were not performed.

Our results suggest that $\mathrm{Co}-3$ and $\mathrm{Co}-9$, previously considered as different genes, are in fact different $\mathrm{R}$ gene combinations (alleles) of the B4 resistance gene 
Table 6. Amplification patterns of markers SB12, OY17, SAH18 and SW12 in 22 genotypes including the 12 differential cultivars and other frequently used resistance sources

\begin{tabular}{|c|c|c|c|c|c|c|c|c|}
\hline & \multicolumn{8}{|c|}{ Molecular markers ${ }^{\mathrm{a}}$} \\
\hline & SB12 & OY17 & SAH18 & & & SW12 & & \\
\hline Cultivar/line & $(350)$ & (1100) & (1100) & $(425)$ & $(475)$ & $(575)$ & $(600)$ & $(700)$ \\
\hline Michelite & - & - & - & - & - & - & - & - \\
\hline MDRK & - & - & - & - & - & - & - & - \\
\hline Perry Marrow & - & - & + & - & - & - & + & + \\
\hline Cornell 49-242 & - & - & - & - & - & - & - & + \\
\hline Widusa & - & - & - & - & - & - & - & - \\
\hline Kaboon & - & - & - & - & - & - & - & + \\
\hline Mexico 222 & - & - & + & + & - & - & - & + \\
\hline PI 207262 & + & + & + & - & + & - & + & + \\
\hline TO & - & - & - & - & - & - & - & + \\
\hline $\mathrm{TU}$ & - & - & + & - & - & - & + & + \\
\hline AB136 & - & - & + & - & - & - & - & - \\
\hline G2333 & - & + & - & - & - & + & + & + \\
\hline SEL 1308 & - & + & + & - & - & - & - & + \\
\hline SEL 1360 & - & - & + & - & - & + & + & + \\
\hline Catrachita & - & - & + & - & - & - & - & - \\
\hline BAT 93 & + & + & + & - & + & - & + & + \\
\hline Jalo EEP558 & - & - & - & - & - & - & - & - \\
\hline Andecha & - & - & - & - & - & - & + & + \\
\hline A321 & + & + & + & - & - & - & - & + \\
\hline A493 & + & + & + & - & + & - & + & + \\
\hline A1231 & + & + & + & - & - & - & - & + \\
\hline A1220 & + & + & + & - & + & - & + & + \\
\hline
\end{tabular}

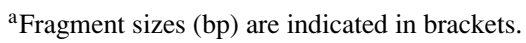

cluster. At present, at least five different alleles at this cluster have been identified: (i) 'A1220', 'A493', 'BAT 93' and 'PI 207262' appear to carry an identical copy of the same allele. This is supported by the identical amplification pattern of the linked markers SB12, OY 17 1100, SAH18 and SW12 in these genotypes (Figure 2). The same allele, from 'A493', conferred resistance to races 38 and 6 and improved the resistance to races 3, 102 and 787 in the resulting progeny line 'A1220' (Table 2). (ii) The allele present in breeding line 'A1231', coming from the resistance donor 'A321', confers resistance to the same five races. However, it may be a different allele, as suggested by the different amplification patterns of the linked marker SW12 (Figure 2d). (iii) The difference between these alleles in 'A1220' and 'A1231' and the one present in 'Mexico 222 ' (Co-3) is greater. 'Mexico 222' shows a different amplification pattern for the three closely linked markers SB12, OY 17 1100 and SW12 (Figure 2) and is susceptible to anthracnose race 102 (Table 2). (iv) The second allele of $\mathrm{Co}-3$ described by Bannerot et al. (1971) in 'Mexico 227', that showed a different resistance pattern from 'Mexico 222', could be a fourth allele of this cluster. (v) Finally, a fifth allele may be present in the Andean landrace 'Jalo EEP558' (Co-y/Co-z) that co-segregated with Co-9 (Geffroy et al., 1999).

Complex clusters of disease resistance genes (Rgenes) are common in plant genomes (Graham et al., 2002). These clusters can span large chromosome segments and confer resistance to different races of the same pathogen as well as to different pathogens. The location of markers SI19, OY $17_{1100}$ and SW12 relatively close to the co-segregating resistances to anthracnose races 38 and 6 of (Figure 1) indicates that the resistance locus on B4 may be an example of resistance gene cluster. Markers SI19 and OY $17_{1100}$ were linked to $U r-5$, a resistance gene for bean rust (Melotto \& Kelly, 1998; Miklas et al., 2002), and the SCAR marker SW12 was linked to a major QTL conferring resistance to bean golden mosaic virus (BGMV) (Miklas et al., 2000).

In these complex gene clusters, variation in R-gene copy number and recombination can play a role in generating diversity (Dixon et al., 1998) and can account for the large allelic differences observed for anthracnose resistance specificity in beans. On the other hand, the pathotype resistance spectra of a bean genotype can be the result of the addition of resistance specificities of two or more independent resistance clusters. For instance, the results obtained in this study (Table 3) indicate that resistance to race 38 of anthracnose in differential cultivar 'PI 207262' is controlled by a single locus. However, segregations corresponding to two independent loci were obtained (Alzate-Marin et al., 2001, 2003) after inoculation with races 65, 73 and 89. Multiple loci complicate the interpretation of the results obtained by different authors concerning allelism tests in which different pathogen races have been used. The use of molecular markers tightly linked to resistance genes can provide additional evidence to solve these anomalies in the literature.

\section{Acknowledgments}

This work was supported by grants AGL2001-2676CO2 and RTA02-052-C2 from the Ministerio de Ciencia y Tecnología, Spain. Astrid Pañeda is recipient of a salary fellowship from the Fundación para el Fomento de la Investigación Científica y Tecnológica (FICYT), Principado de Asturias, Spain. Cristina Rodríguez-Suárez is recipient of a salary fellowship 
from the Ministerio de Ciencia y Tecnología, Spain. Critical evaluation of the manuscript by James D. Kelly at Michigan State University is gratefully aknowledged.

\section{References}

Alzate-Marin, A.L., G.S. Baía, T.J. de Paula Jr, G. Assis de Carvalho, E. Gonçalves de Barros \& M.A. Moreira, 1997. Inheritance of anthracnose resistance in common bean differential cultivar AB136. Plant Dis 81: 996-998.

Alzate-Marin, A.L., K. Souza de Almeida, E. Gonçalves de Barros \& M. Alves Moreira, 2001. Preliminary results of allelism studies for anthracnose resistance genes of common bean cultivar PI 207262. Annu Rep Bean Improv Coop 44: 113-114.

Alzate-Marin, A.L., M.R. Costa, K.M. Arruda, E. Gonçalves de Barros \& M. Alves Moreira, 2003. Characterization of the anthracnose resistance gene present in Ouro Negro (Honduras 35) common bean cultivar. Euphytica 133: 165-169.

Balardin, R.S., A.M. Jarosz \& J.D. Kelly, 1997. Virulence and molecular diversity in Colletotrichum lindemuthianum from South, Central and North America. Phytopathology 87: 1184-1191.

Bannerot, H., M. Deieux \& G. Fouilloux, 1971. Mise en evidence d'un second gene de resistance totale a l'anthracnose chez le haricot. Ann Amélior Plantes 21: 83-85.

Burkholder, W.H., 1918. The production of an anthracnose-resistant white marrow bean. Phytopathology 8: 353-359.

Dixon, M., K. Hatzixanthis, D. Jones, K. Harrison \& J. Jones, 1998. The tomato $C f$-5 disease resistance gene and six homologs show pronounced allelic variation in leucine-rich repeat copy number. Plant Cell 10: 1915-1925.

Ferreira, J.J., M.A. Fueyo, A.J. González \& R. Giraldez, 1998. Pathogenic variability within Colletotrichum lindemuthianum in Northern Spain. Annu Rep Bean Improv Coop 41: 163-164.

Fouilloux, G., 1976. L'anthracnose du haricot (Colletotrichum lindemuthianum, Sacc et Magn): Nouvelles sources de résistance et nouvelles races physiologiques. Ann Amélior Plantes 26: 443-453.

Freyre, R., P.W. Skorch, V. Geffroy, A.-F. Adam-Blondon, A. Shirmohamadali, W.C. Johnson, V. Llaca, R.O. Nodari, P.A. Pereira, S.M. Tsai, J. Tohme, M. Dron, J. Nienhuis, C.E. Vallejos \& P. Gepts, 1998. Towards an integrated linkage map of common bean. Part 4. Development of a core linkage map and alignment of RFLP maps. Theor Appl Genet 97: 847-856.

Geffroy, V., D. Sicard, J.C.F. de Oliveira, M. Sévignac, S. Cohen, P. Gepts, C. Neema, T. Langin \& M. Dron, 1999. Identification of an ancestral resistance gene cluster involved in the coevolution process between Phaseolus vulgaris and its fungal pathogen Colletotrichum lindemuthianum. Mol Plant-Microbe Interact 12: 774-784.
Graham, M.A., L.F. Marek \& R.C. Shoemaker, 2002. Organization, expression and evolution of a disease resistance gene cluster in soybean. Genetics 162: 1961-1977.

Haley, S.D., L.K. Afanador \& J.D. Kelly, 1994. Identification and application of a random amplified polymorphic DNA marker for the $I$ gene (Potyvirus resistance) in common bean. Phytopathology 84: 157-160.

Kelly, J.D. \& R.A. Young, 1996. Proposed symbols for anthracnose resistance genes. Annu Rep Bean Improv Coop 39: 20-24.

Lander, E.S., P. Green, J. Abrahamson, A. Barlow, M.J. Daly, S.E. Lincon \& L. Newburgh, 1987. MAPMAKER: An interactive computing package for constructing primary genetic linkage maps of experimental and natural population. Genomics 1: 174-181.

Mastenbroek, C., 1960. A breeding programme for resistance to anthracnose in dry shell haricot beans based on a new gene. Euphytica 9: 177-184.

Melotto, M. \& J.D. Kelly, 1998. SCAR markers linked to major disease resistance genes in common bean. Annu Rep Bean Improv Coop 41: 64-65.

Melotto, M. \& J.D. Kelly, 2000. An allelic series at the Co-1 locus conditioning resistance to anthracnose in common bean of Andean origin. Euphytica 116: 143-149.

Méndez de Vigo, B., C. Rodríguez, A. Pañeda, R. Giraldez \& J.J. Ferreira, 2002. Development of a SCAR marker linked to Co-9 in common bean. Annu Rep Bean Improv Coop 45: 116-117.

Menezes, J.R. \& J.C. Dianese, 1988. Race characterization of Brazilian isolates of Colletotrichum lindemuthianum and detection of resistance to anthracnose in Phaseolus vulgaris $\mathrm{L}$. Phytopathology 78: 650-655.

Miklas, P.N., R. Delorme, V. Stone, M.J. Daly, J.R. Stavely, J.R. Steadman, M.J. Bassett \& J.S. Beaver, 2000. Bacterial, fungal, virus disease loci mapped in a recombinant inbred common bean population ("Dorado/XAN 176"). J Am Soc Hortic Sci 125: 476-481.

Miklas, P.N., M.A. Pastor-Corrales, G. Jung, D.P. Coyne, J.D. Kelly, P.E. McClean \& P. Gepts, 2002. Comprehensive linkage map of bean rust resistance genes. Annu Rep Bean Improv Coop 45: $125-129$.

Pastor-Corrales, M.A., 1991. Estandarización de variedades diferenciales y de designación de razas de Colletotrichum lindemuthianum (Abstr). Phytopathology 81: 694.

Pastor-Corrales, M.A. \& J.C. Tu, 1989. Anthracnose. In: H.F. Schwartz \& M.A. Pastor-Corrales (Eds.), Bean Production Problems in the Tropics, pp. 77-104. CIAT, Colombia.

Young, R.A. \& J.D. Kelly, 1996. Characterization of the genetic resistance to Colletotrichum lindemuthianum in common bean differential cultivars. Plant Dis 80: 650-654.

Young, R.A. \& J.D. Kelly, 1997. RAPD markers linked to three major anthracnose resistance genes in common bean. Crop Sci 37: 940-946.

Young, R.A., M. Melotto, R.O. Nodari \& J.D. Kelly, 1998. Markerassisted dissection of the oligogenic anthracnose resistance in the common bean cultivar, 'G2333'. Theor Appl Genet 96: 87-94. 